ISSN 2616-7328 (Online), ISSN 2409-904X (Print)

Kitaêznavčì doslìdžennâ, 2018, No. 1, pp. 69-76

UDC 330.35.011:339.96

doi: https://doi.org/10.15407/chinesest2018.01.069

\title{
THEORETICAL AND PRACTICAL ASPECTS OF CHINESE ECONOMY'S INCLUSIVE DEVELOPMENT
}

\author{
O. Khomenko \\ $\mathrm{PhD}$ in International Economics, \\ Senior lecturer at Department of International Economics, \\ Kyiv National Economic University named after Vadym Hetman, \\ 03057, Ukraine, Kyiv, 54/1 Peremohy av. \\ khomenko@kneu.edu.ua
}

This article focuses on the key theories of economic development and the modern concepts of inclusive economic development. The topic presents an analysis of the PRC's economic policy implementation of a strategy for inclusive economic development, as well as an assessment of the results of its fulfilment. This study systematizes the main factors for inclusive development and determines their impact on Chinese economy.

Key words: PRC, inclusiveness, inclusive development, economic growth, Chinese economy

\section{ТЕОРЕТИЧНІ ТА ПРАКТИЧНІ АСПЕКТИ ІНКЛЮЗИВНОГО РОЗВИТКУ ЕКОНОМІКИ КНР}

\section{О. В. Хоменко}

У середині 2000-х років на зміну традиційним моделям економічного розвитку прийшла концепція інклюзивного зростання. Передумовою зміни парадигми економічного розвитку країн є суттєве розшарування суспільства та зростання частки бідного населення внаслідок фінансово-економічних криз та дефіциту факторів виробництва. Головна мета інклюзивного економічного зростання - підвищення добробуту населення, зменшення масштабів бідності та скорочення нерівності в доходах.

\section{Теорії інклюзивного економічного зростання та розвитку}

Теоретичним підгрунтям розвитку теорій інклюзивного зростання стала концепція "перерозподілу в процесі зростання", яка зародилася в 70-х роках минулого століття та основоположниками якої стали Чечери та Ахлувалія [Chenery 1974]. Основана ідея полягає в тому, що політика розумного перерозподілу розширює можливості для ефективного перерозподілу та сприятиме скороченню бідності.

У 2000-х роках виникає теорія “економічного зростання в інтересах бідних" (pro-poor growth), авторами якої були економісти Н. Каквані та Е. М. Пернія. Сутність теорії полягає в тому, що бідність скорочується за умови зростання всіх доходів з однаковою швидкістю. Послідовники цієї теорії Равальйон та Чен визначили ії сутність як зростання, що зменшує рівень бідності [Ravallion 2005].

(C) 2018 O. Khomenko; Published by the A. Yu. Krymskyi Institute of Oriental Studies, NAS of Ukraine and the Ukrainian Association of Sinologists on behalf of The Chinese Studies. This is an Open Access article distributed under the terms of the Creative Commons Attribution License (https://creativecommons.org/licenses/by-nc-nd/4.0/). 
Введення поняття “інклюзивне зростання" було ініційовано Азійський банком розвитку (АБР) у 2007 році. У своєму звіті експерти АБР визначають інклюзивне зростання як зростання, яке сприяє залученню найменш забезпечених верств населення в розширення ринкових можливостей з акцентом на покращення базових послуг у галузі охорони здоров'я, освіти, інфраструктури [Son 2007].

Подібне визначення дають і експерти Організації економічного співробітництва та розвитку: економічний розвиток, у рамках якого виникають можливості для всіх верств населення; справедливо розподіляються матеріальні та нематеріальні блага в суспільстві для підвищення його добробуту [Inclusive Growth 2008]. У цьому контексті мова йде не тільки про подолання прірви між багатими та бідними, а й про рівні умови здобуття освіти, забезпечення охорони здоров'я та безпеки. Тому інклюзивний підхід до зростання передбачає довгострокову стратегію, яка базується на продуктивній зайнятості.

Аналітики Всесвітнього економічного форуму розробили методику оцінки інклюзивного розвитку країн у 2015 році. Це дає змогу визначити, яким чином країни можуть використовувати різноманітний спектр політичних стимулів та інституційних механізмів, щоб зробити економічне зростання більш соціальним [Inclusive Growth Report 2015].

У тому ж році ООН затвердили цілі сталого розвитку, серед яких інклюзивний розвиток. Зокрема, сприяння стійкому, всеосяжному та стабільному економічному зростанню, повноцінній та продуктивній зайнятості й забезпеченню гідної праці для всіх верств населення [Durán 2015].

У травні 2017 році ЄБРР ухвалив Стратегію економічної інклюзивності (2017-2021 рр.). Метою цієї стратегії є прискорення переходу країн до інклюзивної ринкової економіки, використовуючи силу приватного сектора для створення економічних можливостей для усіх [Economic inclusion 2017].

Найпоширеніші методики визначення інклюзивного розвитку країни було розроблено Азійським банком розвитку та Всесвітнім економічним форумом. Відповідно до дослідження АБР фактори, які визначають рівень інклюзивного розвитку, такі: бідність та нерівність у розподілі доходів; економічне зростання та зайнятість; інфраструктура; доступ до освіти та охорони здоров'я; доступ до базових інфраструктурних послуг та послуг; гендерна рівність та можливості; соціальна безпека; уряд та інституції [ADB 2011].

Таким чином, інклюзивне економічне зростання передбачає рівноправний та справедливий розподіл благ, створення умов для повного використання трудового потенціалу та соціальної залученості з метою подолання бідності, базуючись на принципах сталого розвитку.

Інклюзивний розвиток економіки крайни: практичний досвід Китаю

Разом із політикою відкритості, стратегія інклюзивного розвитку стала невід'ємною частиною економічних реформ китайського уряду. Починаючи 3 2004 року, Китай ухвалив концепцію “гармонійного суспільства”, яка базується на принципах інклюзивності: економічне зростання, рівність, сталий та стабільний розвиток. Китайське гармонійне суспільство - це демократія та законність, рівність і справедливість, довіра, співіснування людини та природи.

Стратегія інклюзивного економічного розвитку знайшла своє відображення у П'ятирічних національних планах економічного та соціального розвитку КНР (табл. 1), а також у довгострокових стратегіях до 2030-го та 2050 років, де основною метою є глобальне інноваційне лідерство та інноваційна нація. 
Таблиця 1

Стратегія інклюзивного розвитку в П'ятирічних планах КНР

\begin{tabular}{|c|c|c|}
\hline Період & Стратегічний документ & Особливості та цілі соціального розвитку \\
\hline 2006 & $\begin{array}{l}\text { 11-й П'ятирічний національний } \\
\text { план економічного та соціального } \\
\text { розвитку 2006-2010 }\end{array}$ & $\begin{array}{l}\text { - розбудова гармонійного суспільства пара- } \\
\text { лельно з інноваційним розвитком країни; } \\
\text { - фокус на якості життя населення, екології } \\
\text { та суспільному розвитку; } \\
\text { - побудова “нового соціалізму” в сільській } \\
\text { місцевості }\end{array}$ \\
\hline 2011 & $\begin{array}{l}\text { 12-й П’ятирічний національний } \\
\text { план економічного та соціального } \\
\text { розвитку 2011-2015 }\end{array}$ & $\begin{array}{l}\text { - подолання нерівності та створення серед- } \\
\text { овища для сталого розвитку; } \\
\text { - стимулювання внутрішнього споживання } \\
\text { та попиту; } \\
\text { - покращення соціальної інфраструктури }\end{array}$ \\
\hline 2016 & $\begin{array}{l}\text { 13-й П’ятирічний національний } \\
\text { план економічного та соціального } \\
\text { розвитку 2016-2020 }\end{array}$ & $\begin{array}{l}\text { - створення більш інклюзивного суспільства } \\
\text { та підвищення якості життя, що забезпечить } \\
\text { формування середнього класу, “безпечного” } \\
\text { споживання та надання суспільних послуг }\end{array}$ \\
\hline
\end{tabular}

Джерело: складено автором

Згідно із 13-м П'ятирічним планом, ключовими компонентами економічної стратегії КНР є інноваційна економічна структура, інтенсивна промисловість, скоординовані регіональні системи, зелений розвиток, інклюзивне суспільство, відкритий світогляд та економічні інститути. Саме інклюзивне суспільство передбачає фокус на освіті, науці, культурі та охороні здоров'я, активізацію зусиль у подоланні бідності. Інклюзивна модель розвитку побудована на основі соціальної справедливості та стимулювання внутрішнього споживання.

За даними Central Intelligence Agency, у 2017 році в КНР лише 3,3 \% населення перебували за межею бідності- дохід менш ніж 1,9 дол./день. У 1990 році цей показник становив 66,6 \%, а у 2010 р. - 11,2 \%, 2013 р. - 6,5 \%. Наприклад, в Україні 24,1 \% населення заробляють менш ніж 1,9 дол., США $15,1 \%$, Kopeï - 12,5\%.

За останні 10 років економіка Китаю уповільнила темпи зростання, що саме й обумовлено переорієнтацією на стимулювання внутрішнього попиту. Середньорічні темпи зростання реального ВВП становлять 8,4 \%, а на душу населення - виріс із 3010,9 дол. у 2006 р. до 7329,1 дол. у 2017 р. (рис. 1).

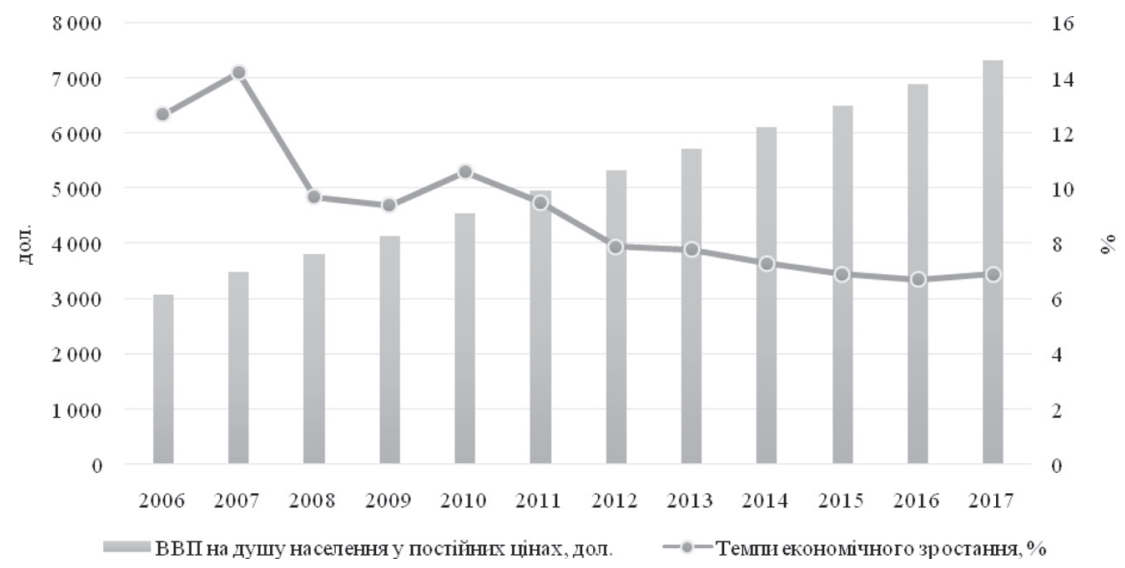

Рис. 1. Динаміка ВВП на душу населення в КНР, дол.

Джерело: UNCTAD 
Зростання доходів на душу населення супроводжується скорочення розриву між багатим та бідним населенням КНР. За даними World Bank, коефіцієнт нерівності розподілу доходів GINI у 2016 році становив 0,465 пунктів, що перевищує рівень “попередження" про підвищений ризик соціальних заворушень, встановлений $\mathrm{OOH},-0,4$ (рис. 2). Такий високий показник свідчить про концентрацію доходів у певних груп населення. Однак протягом останнього десятиліття спостерігається тенденція до зниження коефіцієнта GINI 3 0,487 до 0,465, що є позитивним сигналом для уряду КНР та підтверджує вектор економічної політики.

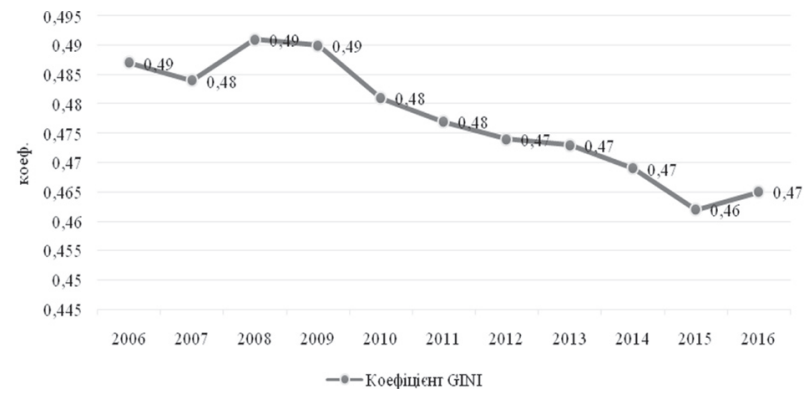

Рис. 2. Динаміка коефіціснта GINI в КНР, 2006-2016 pp.

Джерело: World Bank Data

Одним із пріоритетів інклюзивного економічного зростання КНР є стимулювання внутрішнього попиту та споживання. За допомогою бюджетного стимулювання уряд КНР зменшує залежність від зовнішнього попиту шляхом нарощування внутрішнього. Саме завдяки цьому вдається зберігати зростання економіки Китаю, але з помірним уповільненням.

У 2016 році структура валового внутрішнього продукту була така:

$\checkmark 44 \%$ - інвестиції;

$\checkmark 39,3 \%$ - споживання населення, зокрема 30,7 \% - у містах, 8,6 \% - у селах;

$\checkmark 14 \%$ - державні витрати;

$\checkmark 2,7 \%$ - чистий експорт.

У зв'язку з високим рівнем урбанізації в КНР - майже $55 \%$ - спостерігається зростання витрат на споживання міського населення у середньому на $14 \%$ щорічно. Зовсім інша ситуація в сільській місцевості: за 11 років обсяг витрат на споживання зменшився майже в 3 рази. Саме урбанізація $є$ одним 3 інструментів зменшення розриву між багатими та бідними, а також сприяє формуванню середнього класу.

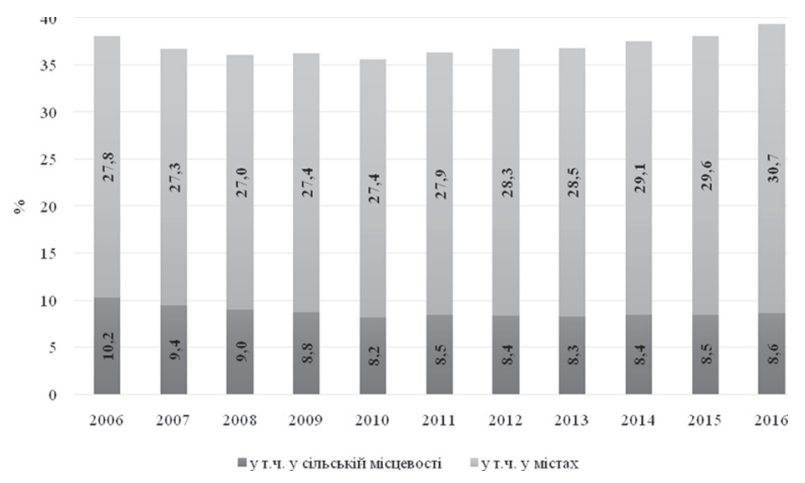

Рис. 3. Динаміка частки споживання населення у структурі ВВП КНР, \% Джерело: Національне статистичне бюро КНР 
За розподілом валового регіонального продукту, п'ятіркою лідерів є провінції (рис.4):

1. Гуандун

8085,49 млрд. юанів;

2. Цзянсу 7738,82 млрд. юанів;

3. Шаньдун 6802,44 млрд. юанів;

4. Чжецзян 4725,14 млрд. юанів;

5. Хенань 4047,18 млрд. юанів.

Найвищі показники ВРП на душу населення в Пекіні (118 тис. юанів), Шанхаї (116 тис. юанів), Тяньцзіні (114 тис. юанів), Цзянсу (96,7 тис. юанів), Чжецзяні (84,5 тис. юанів).

Завдяки регіональним стратегіям економічного та інноваційного розвитку, що обумовили створення сприятливого інвестиційного середовища шляхом відкриття спеціальних економічних, індустріальних, техніко-економічного розвитку та експортних зон, забезпечено виробниче лідерство наведених вище провінцій. У них сконцентровано фінансовий, виробничий, інноваційний потенціал та людський капітал.

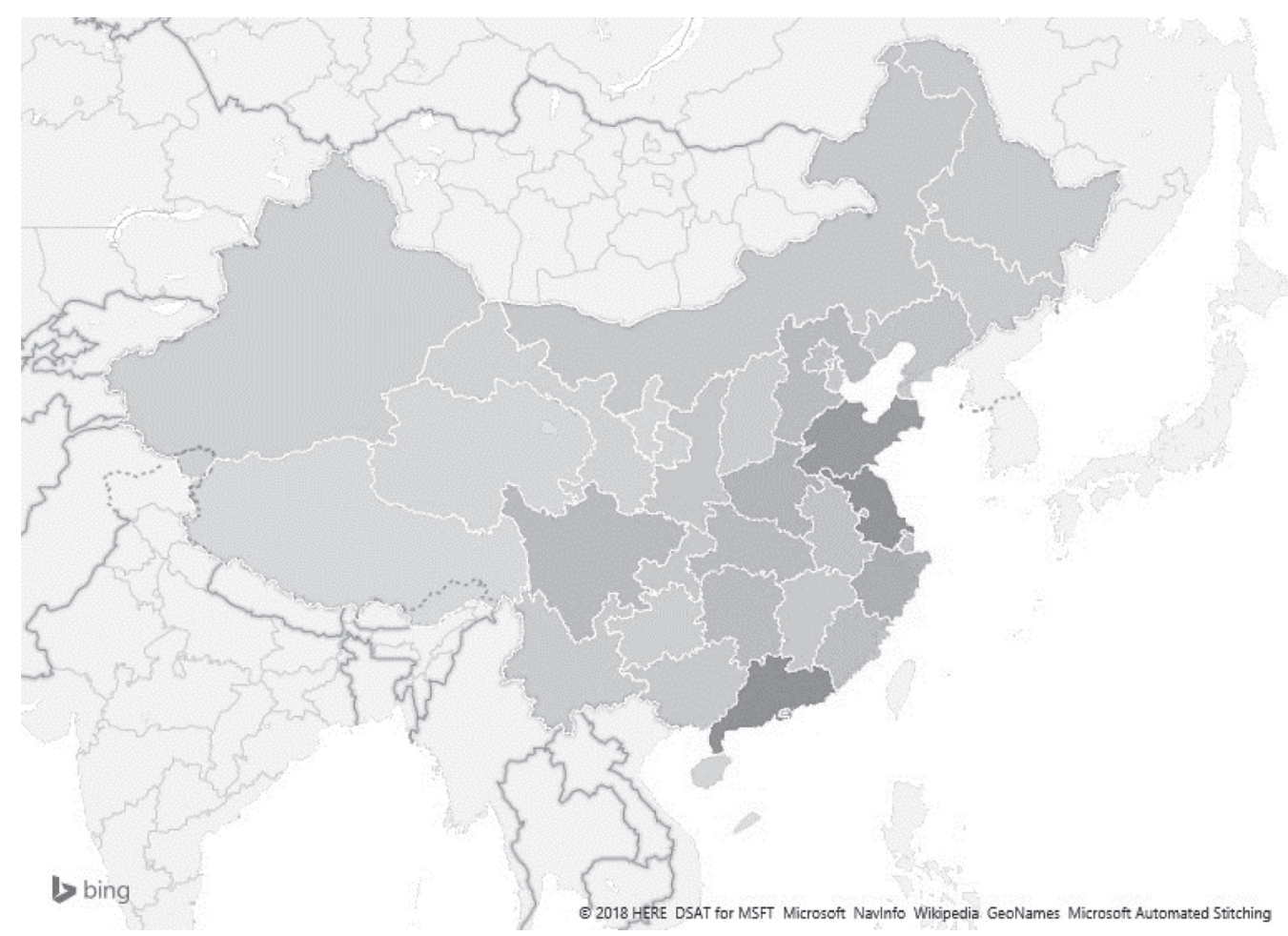

Рис. 4. Валовий регіональний продукт КНР, 2016 р.

Джерело: розроблено автором на основі даних Національного статистичного бюро КНР

Як вже зазначалося, ВВП характеризує виробничу потужність держави, однак для повного аналізу ситуації в країнах необхідно враховувати показники якості життя. За даними Numbeo Database, у 2018 році Китай посідає 55-те місце (індекс - 99,43) за індексом якості життя серед 60 країн - між Бразилією та Філіппінами. Україна займає 57-му позицію $(95,96)$, а лідером є Данія $(197,75)$. 
Серед китайських міст високий рівень якості життя мають Сучжоу $(144,54)$, Ханчжоу $(137,58)$, Ухань $(127,39)$, Ченду $(126,95)$, Фучжоу $(126,63)$, Гуанчжоу $(108,98)$ (рис. 5). Якість життя в зазначених містах забезпечена високим рівнем безпеки, захисту навколишнього середовища, охорони здоров'я, низькими витратами на проживання та швидким трафіком. Натомість забруднення повітря є загальною проблемою для всього Китаю.

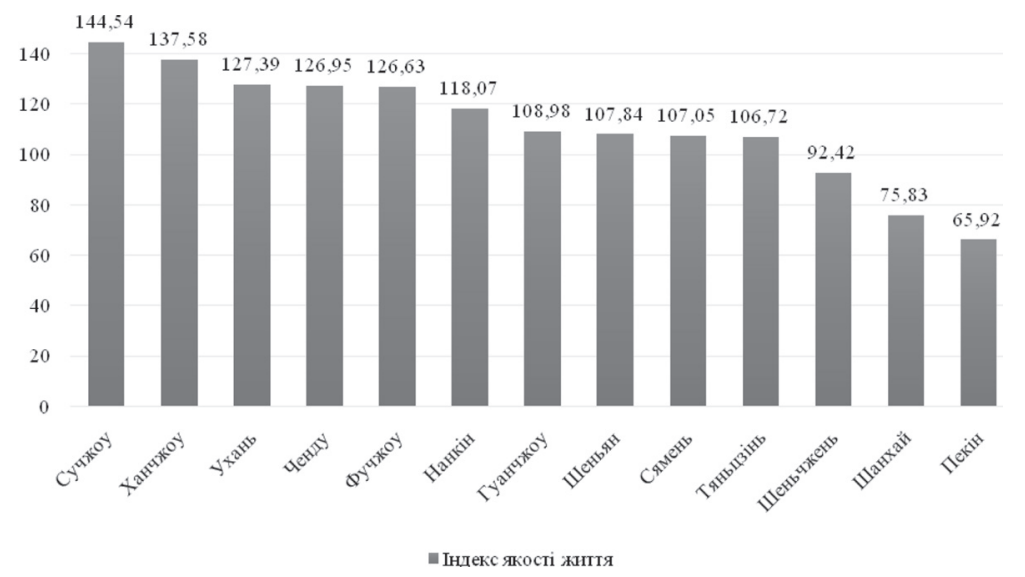

Рис. 5. Індекс якості життя міст КНР, 2017 р.

Джерело: Numbeo Database

Водночас Пекін має низький рівень якості життя $(65,92)$, що обумовлено дуже високим індексом забруднення, повільним трафіком та суттєвими витратами на власність (рис. 6).

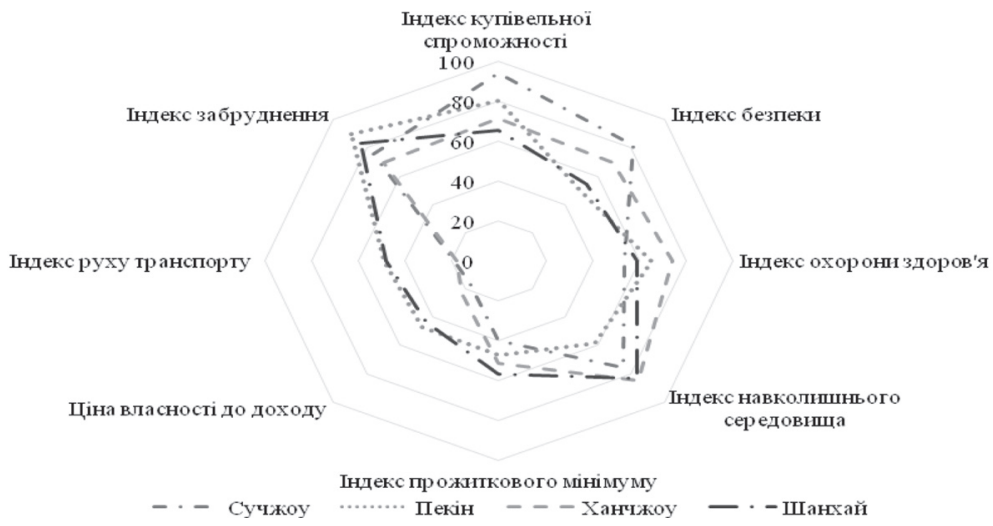

Рис. 6. Субіндекси якості життя деяких міст КНР, 2017 р.

Джерело: Numbeo Database

За оцінками WEF, які представлено у звіті “The Inclusive Development Index 2017”, Китай посідає 15-ту сходинку серед 79 країн, що розвиваються. Конкурентними перевагами КНР $є$ : заощадження, з врахуванням інвестицій у людський капітал; тривалість життя, рівень зайнятості, ВВП на душу населення.

Гальмують інклюзивний розвиток такі фактори: нерівність розподілу доходів та багатства, зростання коефіцієнта демографічного навантаження (відношення чисельності утриманців до працездатного населення), а також інтенсивність викидів діоксиду вуглецю.

За політичними та інституційними індикаторами індексу інклюзивного розвитку сильними сторонами є базові послуги та інфраструктура, освіта, 
зайнятість. Під базовими послугами та інфраструктурою експерти ВЕФ розуміють якість всієї інфраструктури, ефективність наземного транспорту, доступ до електроенергії, частка населення нетрів, частка користувачів Інтернету, кількість абонентів стаціонарного широкосмугового та мобільного Інтернету та його доступність (вартість). До індикатора освіти входять такі субіндикатори, як доступність дошкільної, шкільної та вищої освіти, іiі якість та рівність в отриманні. Зайнятість характеризується

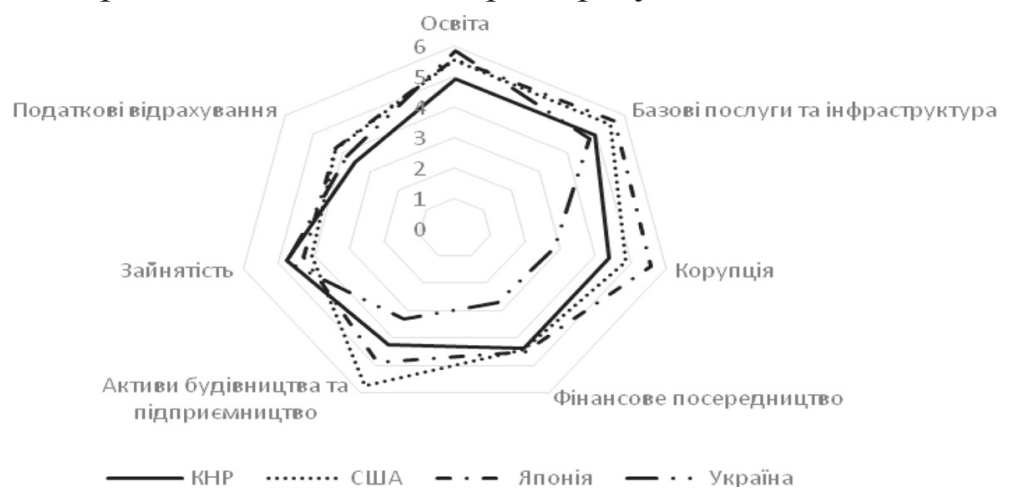

Рис. 7. Політичні та інституційні індикатори індексу інклюзивного розвитку 2017 р. деяких країн за методикою World Economic Forum

У сучасних умовах стале економічне зростання потребує інклюзивного розвитку. Китайський уряд, розуміючи виклики майбутнього та глобальні проблеми людства, взяв курс на внутрішній розвиток у поєднанні з відкритістю та інноваційністю економіки. Це забезпечить у довгостроковій перспективі соціально-економічний ефект у вигляді сталого економічного зростання, доступності середньої та вищої освіти, медицини, формування середнього класу та інноваційної нації.

\section{REFERENCES}

ADB. (2011), Framework of Inclusive Growth Indicators. Retrieved from UN: https://sustainabledevelopment.un.org/content/documents/739indicators.pdf

Chenery, H. M. (1974), Redistribution with Growth. Oxford: Oxford University Press.

Durán, P. (2015), What does inclusive economic growth actually mean in practice? Retrieved from UNDP: http://www.undp.org/content/undp/en/home/blog/ 2015/7/31/What-does-inclusive-economic-growth-actually-mean-in-practice-.html

Economic inclusion (2017), Retrieved from EBRD: https://www.ebrd.com/ what-we-do/projects-and-sectors/economic-inclusion.html

Inclusive Growth (2008), Retrieved from OECD: http://www.oecd.org/inclusive-growth/\#introduction

Inclusive Growth Report (2015), Retrieved from World Economic Forum: https://www.weforum.org/reports/inclusive-growth-report-2015

Ngepah, N. (2017), A review of theories and evidence of inclusive growth: an economic perspective for Africa. Current Opinion in Environmental Sustainability (24), 52-57. doi:10.1016/j.cosust.2017.01.008

Ravallion, M. (2005), Pro-Poor Growth: A Primer. Retrieved from Development Research Group, World Bank: http://siteresources.worldbank.org/INTPGI/ Resources/15174_Ravallion_PPG_Primer.pdf 
Son, H. H. (2007), Pro-Poor Growth: Concepts and Measures. Retrieved from Asian Development Bank: https://www.adb.org/sites/default/files/publication/ 29865/tn-22-pro-poor-growth.pdf

\section{ТЕОРЕТИЧНІ ТА ПРАКТИЧНІ АСПЕКТИ} ІНКЛЮЗИВНОГО РОЗВИТКУ ЕКОНОМІКИ КНР

\section{О. В. Хоменко}

Стаття присвячена ключовим теоріям економічного розвитку та новітнім концепціям інклюзивного розвитку економік країн. У статті представлено аналіз економічної політики КНР щодо імплементації стратегії інклюзивного економічного розвитку, а також оцінку результатів ії реалізації. Дослідження систематизує основні чинники інклюзивного економічного розвитку та визначає вплив на економіку КНР.

Ключові слова: КНР, інклюзивність, інклюзивний розвиток, економічне зростання, китайська економіка

\section{ТЕОРЕТИЧЕСКИЕ И ПРАКТИЧЕСКИЕ АСПЕКТЫ ИНКЛЮЗИВНОГО РАЗВИТИЯ ЭКОНОМИКИ КНР}

\section{О. В. Хоменко}

Аннотация. Статья посвящена ключевым теориям экономического развития и новейшим концепциям инклюзивного развития экономик стран. В статье представлен анализ экономической политики КНР по имплементации стратегии инклюзивного экономического развития, а также оценка результатов ее реализации. Исследование систематизирует основные факторы инклюзивного развития и определяет их влияние на экономику КНР.

Ключовы слова: КНР, инклюзивность, инклюзивное развитие, экономический рост, китайская экономика

Стаття надійшла до редакиії 10.04.2018 